\title{
Comparison of the effect of 8 closures in controlled industrial conditions on the shelf life of a red wine
}

\author{
Jean-Claude Vidal $^{1}$, Soline Caillé ${ }^{2}$, Alain Samson ${ }^{1}$, and Jean-Michel Salmon ${ }^{1}$ \\ ${ }^{1}$ UE999 Pech-Rouge, INRA, 11430 Gruissan, France \\ ${ }^{2}$ UMR SPO, INRA, 34000 Montpellier, France
}

\begin{abstract}
Aims: The management of $\mathrm{O}_{2}, \mathrm{CO}_{2}$ and $\mathrm{SO}_{2}$ at bottling and the choice of the closure are two key factors of the shelf life of wine in bottles before bringing them to market. The impact of four screw caps, two synthetic and two technical corks was evaluated on a red wine of Merlot/Tannat.

Methods and results: Analytical monitoring $\left(\mathrm{O}_{2}, \mathrm{CO}_{2}, \mathrm{SO}_{2}\right.$, aphrometric pressure, $\left.\mathrm{L}^{*}, \mathrm{a}^{*}, \mathrm{~b}^{*}\right)$ was carried out during 538 days of storage at $20^{\circ} \mathrm{C}$. Two sensory analyses at 10 and 17 months completed the study.

The wine was bottled with an average total oxygen content of $2 \mathrm{mg} / \mathrm{L}$. The heterogeneity intra and inter procedure was controlled, including for the dissolved carbon dioxide content.

Conclusion: Unlike closures with highest OTR, the two technical corks and the two screw caps with Saranex seal, harboring the lowest OTR, matched with the wines exhibiting a low total $\mathrm{O}_{2}$ content at equilibrium (from $4^{\text {th }}$ to $18^{\text {th }}$ month), with more free $\mathrm{SO}_{2}$ and less changed colour. However this OTR gradient (5 to $67 \mu \mathrm{g} / \mathrm{d}$ ) observed through the physicochemical analyses was not necessarily confirmed by both sensory analyses performed.

Significance and impact of study: This study puts into perspective the impact of OTR closure on sensory characteristics evolution of wine consumed during the first two years, especially when the total oxygen at bottling exceeds $1.5 \mathrm{mg} / \mathrm{L}$.
\end{abstract}

\section{Introduction}

Oxygen is one of the main factors for wine's evolution. At bottling, oxygen captured in the headspace (HSO) and dissolved in the wine (DO) must be reduced as much as possible. The Oxygen Transmission Rate (OTR) of stopper regulates the transfer of oxygen inside the bottle after bottling. The management of $\mathrm{O}_{2}, \mathrm{CO}_{2}$ and $\mathrm{SO}_{2}$ at filling and the choice of stopper are the key factors of the shelf life, manageable by the conditioner before bringing bottles to market.

The oxygen ingresses during and post bottling lead to the decrease of sulfites. In wine, the reaction between $\mathrm{O}_{2}$ and $\mathrm{SO}_{2}$ is extremely slow [1]. Sulfites react with the products of wine oxidation and in particular with hydrogen peroxide, product of the oxidation of phenolic compounds $[2,3]$. The wine becomes more sensitive to oxidation and ages faster. Godden et al. [4] highlighted a critical concentration of free $\mathrm{SO}_{2}$ of $10 \mathrm{mg} / \mathrm{L}$ below which a Semillon wine is perceived as substantially affected by oxidised aroma. For red wines, controlled oxygen ingresses are necessary and variable according to the expected quality before and after bottling especially to avoid the reduction $[5,6]$.

The commercial choice between stopper (natural, technical or synthetic) and screw cap has a direct impact on the volume and the inerting process of the headspace as well as the OTR of closure. The volume and the management technology of headspace (vacuum, gas sparging, snowdrop) explain that the quantity of oxygen trapped in the headspace can vary from 0.4 to $3.6 \mathrm{mg}$ per bottle as measured by Vidal and Moutounet [7]. The bottling line audits outlined by O'Brien et al. [8] confirm this broad range of oxygen amount. Kontoudakis et al. [9] showed that stopper type significantly affected the HSO content. The volume of the headspace of a corked bottle is significantly lower than this of a capped bottle, but on the other hand the cork releases a portion of the oxygen trapped in its own structure due to the compression of the stopper in the bottleneck [10].

Regarding the bottle position, there is no consensus to date on an effect on oxygen mass transfer through the closure and wine aging over time, even if in theory, the oxygen diffusion coefficient through the closure into wine is smaller than into the headspace. Mas et al. [11] concluded that white and red wines were best preserved when bottles were stored horizontally rather than vertically. Puech et al. [12] on rosé and red wines and Skouroumounis et al. [13] on white wines found no significant differences. Godden et al. [4] concluded that for several closures upright storage tended to accelerate loss of $\mathrm{SO}_{2}$ from a Semillon wine, but in many cases this effect was marginal.

The principal methods for determination of OTR used for wine closures are the coulometric method by Mocon Oxtran and nitrogen flushing of the inner face of the cell [14], the method by permeability meter and pressure difference between the two faces of stopper [15], the luminescence method on corked or capped bottles filled with nitrogen [16] or deoxygenated acid water [17] and 
Table 1. Description of the 8 closures. ${ }^{1}$ PVDC: Polyvinylidene chloride. ${ }^{2}$ OTR: Oxygen Transmission Rate in mg/day/closure given by manufacturer. ${ }^{3}$ OTR, included release, calculated on 1 year. ${ }^{4}$ OTR, included estimated release of $1.5 \mathrm{mg}$ calculated on 1 year.

\begin{tabular}{|c|c|c|c|c|c|c|c|}
\hline Code & Type & $\begin{array}{c}\text { Length } \\
\mathbf{m m}\end{array}$ & $\begin{array}{c}\text { Diameter } \\
\mathbf{m m}\end{array}$ & $\begin{array}{c}\text { Weight } \\
\mathbf{g}\end{array}$ & $\begin{array}{c}\text { Density } \\
\mathbf{k g} / \mathbf{m}^{\mathbf{3}}\end{array}$ & $\begin{array}{c}\mathbf{O T R}^{\mathbf{2}} \\
\mathbf{m g} / \mathbf{d}\end{array}$ & $\begin{array}{c}\text { Method of OTR } \\
\text { measurement }\end{array}$ \\
\hline B1 & Synthetic stopper & 42 & 22.5 & 4.8 & 285 & $0.014^{3}$ & Luminescence \\
\hline B2 & Technical stopper & 44 & 24.5 & 5.6 & 270 & $0.005^{4}$ & Coulometry \\
\hline B3 & Technical stopper & 44 & 24.0 & 5.7 & 280 & $0.005^{3}$ & Colorimetry \\
\hline B4 & Synthetic stopper & 42 & 22.0 & 7.6 & 488 & 0.047 & \multirow{2}{*}{ Coulometry } \\
\hline C1 & Screw caps + Saranex seal & & 31.5 & & & 0.005 & \multirow{2}{*}{ C2 } \\
\hline C2 & Screw caps + Saranex seal & & 31.5 & & & 0.005 & \\
\hline C3 & Screw cap + seal without PVDC & & 31.5 & & & 0.067 & \\
\hline C4 & Screw cap + seal without PVDC & & 31.5 & & & 0.007 & \\
\hline
\end{tabular}

the colorimetric method with indigo carmine [18]. The Mocon Oxtran technology is by far the most commonly used in the packaging industry. But when applied to the bottle/closure system, it cannot mimic exactly the configuration of storage where the closure is wet with wine or in contact with water vapor saturated headspace in case of vertical storage. Moreover, another major drawback of this method is the long time required to reach the steady state of oxygen ingress through the closure when $40 \mathrm{~mm}$ long stoppers are tested [19]. These reasons explain why manufacturers use also methods with operating conditions closer to enological reality and which better integrate the desorption of oxygen by the stopper mainly during the first month as luminescence and colorimetric methods $[16,20]$.

However, whatever the used method, the OTR range of natural corks is roughly intermediate between this of screw cap and technical stoppers and this of synthetic stoppers, but with a greater heterogeneity by comparison with industrial stoppers $[15,18,21,22]$.

Logically, many studies have shown the impact of OTR on the quality of wines. Also the higher oxygen permeability it is, the higher are decrease in the $\mathrm{SO}_{2}$ level, increase of the absorbance at $420 \mathrm{~nm}$ and premature emergence of oxidised aroma for white wines [4, 13, 23-25]. Conversely, screw caps are cited by the majority of the previous articles as closures for which sensorial reduction notes are most frequent due to their low OTR.

Generally speaking, the red wine behaved in a similar way to the white wine, but thanks to its higher phenolic compounds content, it was much more resistant to oxidation [11] but also sensible to reduction when oxygen ingresses post-bottling are insufficient $[5,6]$, in particular with screw caps [26].

Thus, for entry and mid-range wines, synthetic or technical stoppers and aluminum caps usually supersede natural corks.

Based on these findings, an experimental protocol was set up in order to answer the following questions. What is the impact of these closures on the shelf life of a red wine bottled at an industrially achievable Total Oxygen content $\left(\mathrm{TO}_{2}\right)$ and intended to be drunk within two years? Are there differences between stoppers and screw caps? Which physicochemical and sensory characteristics are influenced significantly by the oxygen permeability of the closure? To the best of knowledge, this is one of first studies based on the relationship between OTR and the consumptions of oxygen and sulfites under industrial conditions controlled by dissolved gases and sulfites.

\section{Material and methods}

\subsection{Experiment}

A 2013 IGP Côtes de Gascogne red wine (70\% Merlot + $30 \%$ Tannat) was bottled on 26 June 2015 at INRA PechRouge bottling facility (Gruissan, France) in $75 \mathrm{cL}$ flint glass Bordeaux bottles at targeted levels of $\mathrm{O}_{2}, \mathrm{CO}_{2}$ and $\mathrm{SO}_{2}$ and with a weak dispersion. Two synthetic stoppers (B1, B4), two technical stoppers (B2, B3), two screw caps with Saranex seal $(\mathrm{C} 1, \mathrm{C} 2)$ and two screw caps $(\mathrm{C} 3, \mathrm{C} 4)$ with seal without Polyvinylidene chloride (PVDC) were tested (Table 1). The two types of closure and the different length of stoppers (42 or $44 \mathrm{~mm}$ ) led to different headspace volumes and inerting processes. The target $\mathrm{TO}_{2}$ in bottle was set at $1.5 \mathrm{mg} / \mathrm{bt}(2 \mathrm{mg} / \mathrm{L})$, a value reasonably achievable at the industrially level whatever the closure used.

After bottling, bottles were stored upright in the dark in a thermostatically controlled room at $19.9 \pm 0.5^{\circ} \mathrm{C}$, with $67.2 \pm 15.8 \% \mathrm{HR}$ (monitored, but not controlled). Both destructive and non-destructive physicochemical analyses were carried out on several dates spread over 538 days after bottling. An expert jury performed sensory analysis at $10^{\text {th }}$ and $17^{\text {th }}$ months.

Given the small thickness of the seal, the oxygen release of screw caps is negligible as shown by Vidal et al. [17]. For stoppers, as discussed in the introduction, manufacturers generally prefer the luminescence and colorimetric methods of OTR measurement to better quantify the higher release of oxygen by stopper at the beginning of storage which significantly increases the OTR. The coulometry tends to undervalue this phenomenon and gives an OTR of $0.009 \mathrm{mg} / \mathrm{d}$ lower than the luminescence method for B1 $(0.014 \mathrm{mg} / \mathrm{d})$. The OTR of $\mathrm{B} 2$ by coulometry is enhanced by an estimated release of $1.5 \mathrm{mg}$. For the stoppers B3 and B4, manufacturers have provided OTR value obtained by a single method presented in Table 1.

\subsection{Bottles}

Cork bottles: OI (Villeurbanne, France), standard 75cL BD CAR II LG, unfilled level $63 \mathrm{~mm}$; screw cap bottles: OI, standard 75cL BD CAR II LG BVS, unfilled level $45 \mathrm{~mm}$.

\subsection{Analyse of wine just after bottling}

$12.9 \%$ vol.; sugar $2.6 \mathrm{~g} / \mathrm{L}$; TA $3.33 \mathrm{~g} \mathrm{H}_{2} \mathrm{SO}_{4} / \mathrm{L}$; VA $0.43 \mathrm{~g}$ $\mathrm{H}_{2} \mathrm{SO}_{4} / \mathrm{L} ; \mathrm{pH} 3.49$; free $\mathrm{SO}_{2} 27 \pm 0 \mathrm{mg} / \mathrm{L}$; total $\mathrm{SO}_{2}$ 
$68 \pm 0 \mathrm{mg} / \mathrm{L} ; \mathrm{CO}_{2} 325 \pm 15 \mathrm{mg} / \mathrm{L} ; \mathrm{L} * 67.21 ; \mathrm{a}^{*} 33.89 ; \mathrm{b}^{*}$ 8.91; $\mathrm{A}_{420}$ 2.532; $\mathrm{A}_{520}$ 3.379; $\mathrm{A}_{620}$ 0.633, Total Phenol Index $=49$.

\subsection{Bottling}

The INRA Pech-Rouge bottling line for experimental wines allowed the control and management of dissolved gases on the three elements of the chain:

- a filtration skid (RS IW, Tübingen, Germany) with preparation tank $(105 \mathrm{~L})$, prefiltration $(1 \mu \mathrm{m})$ and final filtration $(0.65 \mu \mathrm{m})$,

- a single head filler MTB 1/1 (Perrier, Le Cheylar, France) with or without neutral gas flushing of filler tank (46 L) and bottles before filling,

- a single head corking machine Gemini R (Arol, Canelli, Italy) with coupling vacuum and inert gas $\left(\mathrm{N}_{2}\right.$ for this study) in several cycles before corking in order to reduce the oxygen amount of the headspace.

This line achieves homogeneous bottling of small volumes of wines with very low variations in $\mathrm{TO}_{2}$ and dissolved $\mathrm{CO}_{2}[27,28]$.

Four batches of $100 \mathrm{~L}$ were required for the filling of the 450 bottles of the study. The preparation tank was filled by gravity with the starting tank of red wine. The wine was sparged with $\mathrm{N}_{2}$ gas using a porous injector bolted to the bottom of the preparation tank until DO reached $0.15 \mathrm{mg} / \mathrm{L}$ then adjusted to $300 \mathrm{mg} / \mathrm{L}$ of dissolved carbon dioxide $\left(\mathrm{DCO}_{2}\right)$ by sparging with $\mathrm{CO}_{2}$ gas

The circuit was purged with $\mathrm{N}_{2}$ from the outlet of preparation tank to head filler machine. Wine was forced into the circuit by $\mathrm{N}_{2}$ to the filler tank through the filtration skid using overpressure of $100 \mathrm{kPa}$ applied to the top of preparation tank. Bottles were blanketed before filling. A slight depression of $8 \mathrm{KPa}$ assisted the filling height adjustment.

Filled cork bottles were sealed by the single head corking machine. 2 combined cycles of $\mathrm{N}_{2}(1 \mathrm{~s})$ followed by vacuum $75 \mathrm{KPa}$ ( $1 \mathrm{~s}$ ) were performed. Filled screw cap bottles were crimped by a single head capping machine Galaxy (Costral, Riquewihr, France) without inerting of headspace and cap. The unscrewing torque has been checked for the four kinds of screw cap bottles with Orbis $6 \mathrm{Nm}$ digital torque tester (Mecmesin, Slinfold, England).

Since the DO has been set to a low level for all procedures, the $\mathrm{TO}_{2}$ target value of $1.5 \mathrm{mg} / \mathrm{bt}$ was reached thanks to the management of the headspace according to the type of bottle and its unfilled level.

\subsection{Physicochemical analyses}

On line $\mathrm{O}_{2}$ monitoring was performed using a PreSens luminescent probe and PSt3 $\mathrm{O}_{2}$-sensitive optical spots (PreSens Precision Sensing GmbH, Regensburg, Germany) integrated at four checkpoints on the bottling line and at the top and bottom of the preparation and filler tanks. $\mathrm{DCO}_{2}$ was monitored by sampling in the preparation tank using a Carbodoseur (Dujardin-Salleron laboratories, Noizay, France).

The following destructive analyses were performed at T0, 1, 4, 8, 12 and 18 months: aphrometric pressure (simplified aphrometer for still wines, Ligapal,
Table 2. Sensory attributes selected and composition of their reference standards. ${ }^{1}$ Attributes added at 17 months.

\begin{tabular}{|c|c|c|}
\hline $\begin{array}{c}\text { Sensory } \\
\text { cluster }\end{array}$ & $\begin{array}{c}\text { Attribute } \\
\text { Attribute }\end{array}$ & Reference standard \\
\hline Visual & Colour intensity & \\
\hline & Amylic & Isoamyl acetate \\
& Animal (leather) & 4-Ethylphenol \\
& Cooked red fruits & Red fruits jam \\
Olfactory & Dry wood (dust) & Unheated wood powder $^{1}$ \\
& Pastry (vanilla, & Caramel syrup \\
& caramel) & Black pepper \\
\hline \multirow{5}{*}{ Gustatory } & Pepper & Grape stem tannin \\
& Astringency & extract \\
& Bitterness & Caffeine \\
& Sourness & Tartaric acid \\
& Sweetness ${ }^{1}$ & Grape sugar \\
& Alcohol & Absolute ethanol \\
\hline
\end{tabular}

Cormontreil, France); free and total $\mathrm{SO}_{2}$ (potentiometric titration, Titromatic, Crison Instruments, Alella, Spain); $\triangle \mathrm{Eab}^{*}$ (spectrophotometer CM3600d, Konica Minolta, Roissy CDG, France, standard illuminant D65, 10 standard observer). Non-destructive monitoring was conducted every month from $\mathrm{T} 0$ to 18 months for unfilled level (set square for wine bottle), calculation of the volume of headspace, dissolved and gaseous $\mathrm{O}_{2}$ (luminescence with PreSens PSt3 glued spots inside bottles) and dissolved $\mathrm{CO}_{2}$ (laser spectroscopy, Lsensor $\mathrm{CO}_{2}$, FT System, Padova, Italy). For destructive and non-destructive chemical analyses, three repetitions were performed by parameter / procedure / date.

Twelve bottles capped with $\mathrm{C} 4$ screw cap were stored at $7{ }^{\circ} \mathrm{C}\left(\mathrm{C} 47^{\circ} \mathrm{C}\right)$. These bottles were used for $\mathrm{SO}_{2}$ analyses at 243,370 and 532 days.

\subsection{Sensory analyses}

Descriptive quantitative analysis was conducted by an expert sensory panel (22 judges), selected on the basis of their sensory performances and interest (ISO 8586-2, 1994), and trained to descriptive sensory analysis of wines. At the first step of generating vocabulary, the jury selected attributes by consensus, to describe the samples. The Table 2 presents the finally selected attributes. Then the panelists were trained to understand and consistently use attributes and familiarized with the product space. Finally, the judges rated each attribute on an unstructured linear scale from "low" to "high". For olfactory and taste analyses, wines were evaluated in duplicate, in monadic service, according to a random order (Latin square) minimizing carry-over effects, in black tulipshaped glasses to ensure that visual perceptions did not influence olfactory and taste analyses, between 17 and $19^{\circ} \mathrm{C}$. Following for visual attributes, samples were evaluated in comparative service, in $215 \mathrm{ml}$ wine glasses, with "normal daylight" illumination.

Sensory data were converted into marks from 0 to 10 by Fizz Software version 2.40 A (Biosystemes, Couternon, France).

\subsection{Statistical analyses}

Statistical analyses were performed using XLSTAT software version 2014 (Addinsoft, Paris, France). 
Table 3. Contents of $\mathrm{O}_{2}$ at bottling and $\mathrm{TO}_{2}$ at equilibrium. HSO: Headspace Oxygen; DO: Dissolved Oxygen; $\mathrm{TO}_{2}$ : Total Oxygen; $\mathrm{mg} / \mathrm{bt}$ : mg/bottle. ${ }^{1} \mathrm{TO}_{2}$ at equilibrium: average $\mathrm{TO}_{2}$ between $90^{\text {th }}$ and $532^{\text {th }}$ day. Averages and standard deviations are based on 3 bottles per procedure.

\begin{tabular}{|c|c|c|c|c|c|}
\hline & & \multicolumn{3}{|c|}{ T0 } & \\
\hline Type & Code & HSO mg/bt & DO mg/bt & $\mathrm{TO}_{2} \mathrm{mg} / \mathrm{bt}$ & $\begin{array}{c}\mathrm{TO}_{2} \text { equilibrium } \\
\text { mg/bt }^{1}\end{array}$ \\
\hline \multirow{4}{*}{ Stopper } & B1 & $1.08 \pm 0.00$ & $0.15 \pm 0.06$ & $1.22 \pm 0.06$ & $0.06 \pm 0.02$ \\
\hline & B2 & $1.19 \pm 0.12$ & $0.19 \pm 0.05$ & $1.38 \pm 0.09$ & $0.04 \pm 0.01$ \\
\hline & B3 & $1.03 \pm 0.07$ & $0.30 \pm 0.19$ & $1.34 \pm 0.17$ & $0.05 \pm 0.01$ \\
\hline & B4 & $0.99 \pm 0.07$ & $0.25 \pm 0.05$ & $1.24 \pm 0.12$ & $0.11 \pm 0.06$ \\
\hline \multirow{4}{*}{ Screw cap } & $\mathrm{C} 1$ & $1.43 \pm 0.21$ & $0.19 \pm 0.03$ & $1.62 \pm 0.18$ & $0.04 \pm 0.01$ \\
\hline & $\mathrm{C} 2$ & $1.46 \pm 0.17$ & $0.18 \pm 0.03$ & $1.64 \pm 0.17$ & $0.05 \pm 0.01$ \\
\hline & $\mathrm{C} 3$ & $1.61 \pm 0.25$ & $0.15 \pm 0.03$ & $1.75 \pm 0.28$ & $0.23 \pm 0.03$ \\
\hline & $\mathrm{C} 4$ & $1.54 \pm 0.07$ & $0.20 \pm 0.09$ & $1.74 \pm 0.13$ & $0.07 \pm 0.02$ \\
\hline \multicolumn{2}{|c|}{ Stoppers averages } & $\begin{array}{c}1.07 \pm 0.06 \\
(10.4 \pm 0.6 \% \mathrm{v} / \mathrm{v})\end{array}$ & $=0.09$ & 1 & \\
\hline \multicolumn{2}{|c|}{$\begin{array}{c}\text { Screw caps } \\
\text { averages }\end{array}$} & $\begin{array}{c}1.51 \pm 0.17 \\
(7.9 \pm 0.9 \% \mathrm{v} / \mathrm{v})\end{array}$ & $0.18 \pm 0.05$ & $\mathbf{1 . 6 9} \pm 0.19$ & \\
\hline
\end{tabular}

For sensory data, after confirming jury good performances (repeatability, consensus and discrimination), results were processed by analysis of variance ( 2 factors: judge and wine). When significant differences were revealed ( $\mathrm{p}<0.05)$, mean intensities were compared using the Tukey (HSD) multiple comparison test.

The results of free - total $\mathrm{SO}_{2}$ and consumption ratios of $\mathrm{SO}_{2} / \mathrm{O}_{2}$ were processed by analysis of variance (1 factor: closure). When significant differences were revealed $(\mathrm{p}<0.05)$, analytical parameters were compared using the Tukey (HSD) multiple comparison test.

The treatment allowed to classify the different wines in several distinguishes groups (A, B, C, D, E). The average values and the several groups are given in this paper.

\section{Results and discussion}

\subsection{Industrial bottling parameters}

The unscrewing torque of capped bottles tested after crimping was on average $16 \pm 1 \mathrm{lbf} /$ inch for all four screw caps procedures. The unfilled level which determines the volume of the headspace was on average $63 \pm 2 \mathrm{~mm}$ for the stoppers and $45 \pm 2 \mathrm{~mm}$ for screw caps (net of seal thickness) from T0 to $538 \mathrm{~d}$. Aphrometric pressure fluctuated between -160 and $200 \mathrm{kPa}$ from T0 to $538 \mathrm{~d}$. The monitoring of these three parameters was in accordance with usual technical recommendations.

\subsection{Dissolved gases}

Just after bottling, $86 \%$ of $\mathrm{TO}_{2}\left(\mathrm{TO}_{2}=\mathrm{HSO}+\mathrm{DO}\right)$ was located in the headspace of bottle. The average $\mathrm{TO}_{2}$ was $1.5 \mathrm{mg} / \mathrm{bt}(2 \mathrm{mg} / \mathrm{L})$. Heterogeneity remained limited because the highest intraprocedural standard deviation was $0.28 \mathrm{mg} / \mathrm{bt}$ (Table 3) and the maximum intraprocedural deviation was $0.53 \mathrm{mg} / \mathrm{bt}$ (between B1 and C3). As already described several times [29-31], both oxygen in the headspace and dissolved in the wine were consumed. This decrease was not linear because $90 \%$ of initial $\mathrm{TO}_{2}$ was consumed after 35 days. From $48^{\text {th }}$ day, $\mathrm{TO}_{2}$ was less than $0.10 \mathrm{mg} / \mathrm{bt}$, except for B4 and C3. These procedures had the most variable and highest $\mathrm{TO}_{2}$ content, mainly

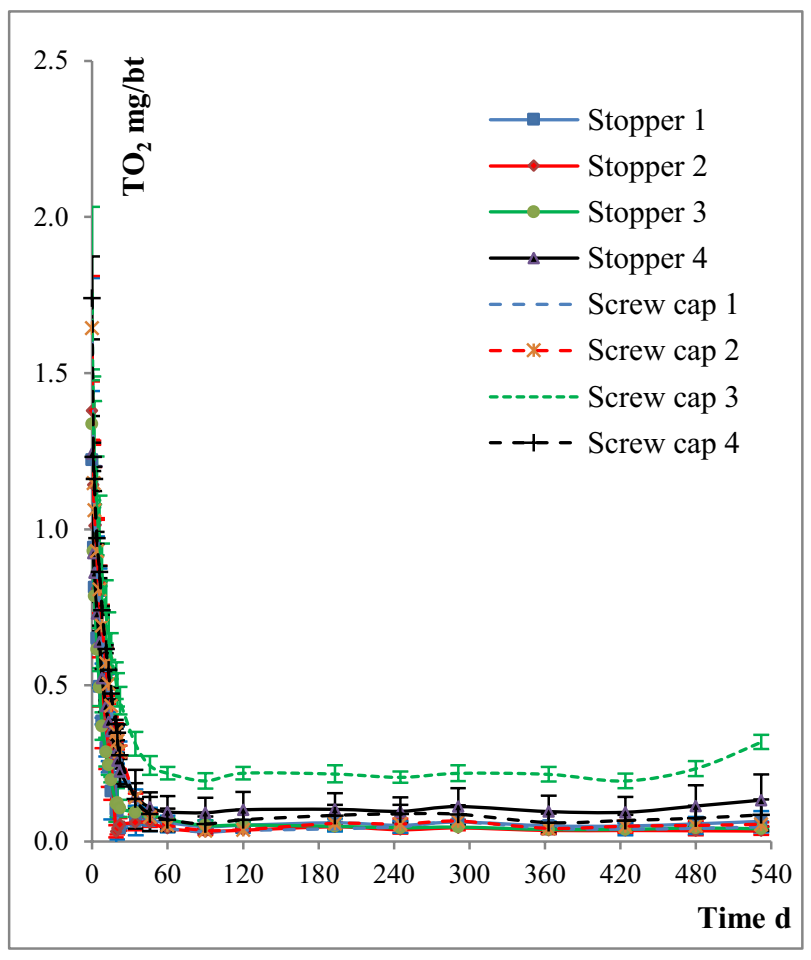

Figure 1. $\mathrm{TO}_{2}=\mathrm{f}(\mathrm{t})$ for each procedure. $\mathrm{TO}_{2} \mathrm{mg} / \mathrm{bt}$ : Total oxygen in $\mathrm{mg} / \mathrm{bottle}$. Averages and standard deviations are based on 3 bottles per procedure.

due to HSO level (higher than $0.1 \mathrm{mg} / \mathrm{bt}$ at $532 \mathrm{~d}$ ), while the DO level was equivalent to other procedures (around $0.01-0.02 \mathrm{mg} / \mathrm{bt}$ ). Beyond the $90^{\text {th }}$ day, we could consider that all closures reached their steady states (Fig. 1). The $\mathrm{TO}_{2}$ stabilized at an equilibrium value which was the resultant of $\mathrm{O}_{2}$ ingresses by the closure and $\mathrm{O}_{2}$ consumption by the wine, for the same wine and in the same storage conditions. Thus we could link the closure OTR to the average $\mathrm{TO}_{2}$ between $90^{\text {th }}$ and $532^{\text {th }}$ day (Tables 2 and 3 ).

The carbon dioxide concentration remained stable up to 532 days, except for the B4 procedure for which the 
losses represented $18 \%$ corresponding to a loss of $60 \mathrm{mg} / \mathrm{L}$, less than the sensory perception threshold.

\subsection{Colour}

The distance between two colours $\left(\Delta \mathrm{Eab}^{*}\right)$ was used to summarise the evolution of the colour of wine between $\mathrm{T} 0$ and $538 \mathrm{~d}$.

$$
\Delta E a b^{*}=\sqrt{\left(L_{0}-L_{538 d}\right)^{2}+\left(a_{0}-a_{538 d}\right)^{2}+\left(b_{0}-b_{538 d}\right)^{2}}
$$

Over time, $b^{*}$ increased and a* decreased, colour tended gradually to tile colour. After $538 \mathrm{~d}$, the $\Delta \mathrm{Eab}^{*}$ varied between 6.6 and 8.3 regardless of the procedure. C4, B1, $\mathrm{B} 3$ and $\mathrm{C} 2$ were the procedures whose colour has changed the least unlike B4 and C3. However, even if the $\Delta \mathrm{Eab}^{*}$ between $\mathrm{T} 0$ and $370 \mathrm{~d}(538 \mathrm{~d})$ were at least 4.8 (6.6), the maximum interprocedural deviation was $1.7\left(\triangle \mathrm{Eab}^{*}=\right.$ 8.3-6.6 respectively for B4 - C4 at $538 \mathrm{~d}$ ). The evolution of colour of wine until $538 \mathrm{~d}$ is mainly due to the aging of wine. By comparison, the $\Delta \mathrm{Eab}^{*}$ after 18 months storage is less than 1 between wines of Cabernet Sauvignon sealed by natural cork, synthetic closure and screw cap with $16 \mathrm{~mL}$ of headspace volume [26].

Meanwhile, the colour of red wine stored at $7{ }^{\circ} \mathrm{C}$ changed very little because $\Delta \mathrm{Eab}^{*}=0.6$ and 1.1 respectively at 370 and $538 \mathrm{~d}$.

And so until 18 months, the temperature impact on the colour is clearly greater than this of stopper.

\subsection{Sulfites}

From $370 \mathrm{~d}$, the dispersion stayed or extended between the $\mathrm{C} 1, \mathrm{C} 2, \mathrm{~B} 2$ procedures for which the free $\mathrm{SO}_{2}$ was at least $11 \mathrm{mg} / \mathrm{L}$ and the $\mathrm{B} 4$ and $\mathrm{C} 3$ procedures for which the free $\mathrm{SO}_{2}$ toggled below the threshold of $10 \mathrm{mg} / \mathrm{L}$; the $\mathrm{B} 3$, $\mathrm{C} 4$ and $\mathrm{B} 1$ procedures exhibiting an intermediate position (Fig. 2a). The distribution of stoppers is the same for total $\mathrm{SO}_{2}$ (Fig. 2b).

However it should be mentioned that the impact of the stopper on the free $\mathrm{SO}_{2}$ conservation reached a maximum of $5 \mathrm{mg} / \mathrm{L}$ between the procedures at 538 days (Fig. 2a) that is to say below the value of $7 \mathrm{mg} / \mathrm{L}$ of the expanded uncertainty for free $\mathrm{SO}_{2}$ content of 10 to $30 \mathrm{mg} / \mathrm{L}$ [32]. Only the cold treatment had a clear effect on the preservation of free $\mathrm{SO}_{2}$, as $\mathrm{SO}_{2}$ consumption reactions slowed (free $\mathrm{SO}_{2}$ at $538 \mathrm{~d}=10 / 25 \mathrm{mg} / \mathrm{L}$ for $\mathrm{C} 4 / \mathrm{C} 47^{\circ} \mathrm{C}$ ).

\subsection{Sulfite versus oxygen consumption}

Oxidation of phenolic compounds leads to the production of quinones and hydrogen peroxide. $\mathrm{SO}_{2}$ reacts with the latter, thus preventing the oxidation of ethanol according to the Fenton reaction, and reduces quinones towards their initial phenolic form. Under ideal experimental conditions, the $\mathrm{O}_{2}: \mathrm{SO}_{2}$ molar ratio of the reaction is 1:2 [33], corresponding to a maximum theoretical consumption of $4 \mathrm{mg}$ of $\mathrm{SO}_{2}$ per $\mathrm{mg}$ of consumed $\mathrm{O}_{2}$. During storage of wine in bottle, a mass ratio below 4 or a molar ratio of $1:<2$ means that a part of the oxygen which enters inside the bottle does not indirectly reacts with $\mathrm{SO}_{2}$, but reacts with other constituents of wine [33,34]. Nucleophilic compounds come into competition with sulfites to react

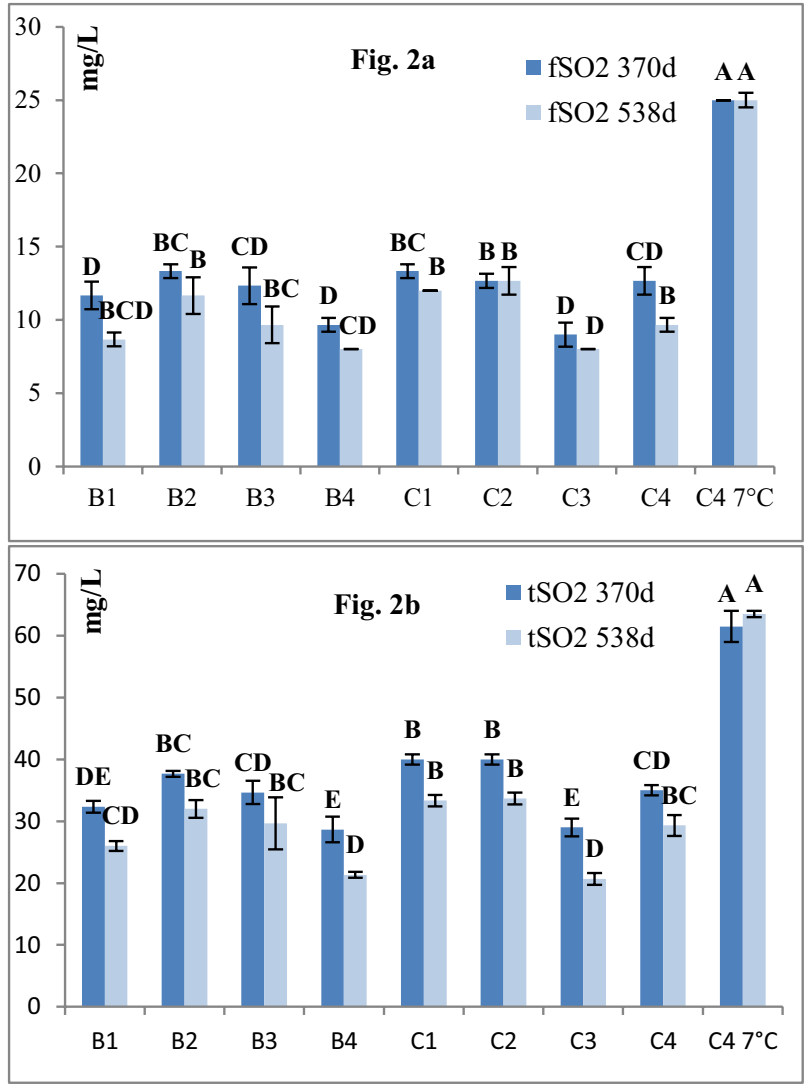

Figures 2a and 2b. Free $\mathrm{SO}_{2}$, total $\mathrm{SO}_{2}$ at 370 and 538 days. Stoppers B1 to B4; screw caps C1 to C4. Different labels (A, $\mathrm{B}, \mathrm{C}, \mathrm{D}, \mathrm{E})$ indicate means that significantly differ at $\mathrm{p}<0.0001$. Averages and standard deviations are based on 3 bottles per procedure. $\mathrm{fSO}_{2}$ : free $\mathrm{SO}_{2} ; \mathrm{tSO}_{2}$ : total $\mathrm{SO}_{2}$ in $\mathrm{mg} / \mathrm{L}$; d:day. Free and total $\mathrm{SO}_{2}$ at $\mathrm{T} 0=27 \pm 0 / 68 \pm 0 \mathrm{mg} / \mathrm{L}$.

with the quinones. Waterhouse et al. [35] uses the mass ratios with free $\mathrm{SO}_{2}$ consumption ( $\left(\mathrm{fSO}_{2}\right)$ and total $\mathrm{SO}_{2}$ consumed $\left(\mathrm{tCSO}_{2}\right)$ to evidence this phenomena: more the mass ratio is less than 4 and more the oxidation of other wine constituents is important.

$$
\begin{aligned}
& T C O_{i} \frac{m g}{L}= \\
& \left(T O_{2 T 0}-T O_{2 i}\right) \frac{m g}{b t} / 0,75+(O T R \times \text { idays })
\end{aligned}
$$

Free Consumed $\mathrm{SO}_{2} / \mathrm{TCO}=$

$$
\frac{f C S O_{2} \frac{m g}{L}}{T C O \frac{m g}{L}} i d a y s=\frac{f S O_{2} T 0-f S O_{2} i}{T C O_{i}}
$$

Total Consumed $\mathrm{SO}_{2} / \mathrm{TCO}=$

$$
\frac{t C S O_{2} \frac{m g}{L}}{T C O \frac{m g}{L}} i d a y s=\frac{t S O_{2} T 0-t f \mathrm{SO}_{2} i}{T C O_{i}}
$$

The ranking of stoppers in descending order of $\mathrm{fCSO}_{2} / \mathrm{TCO}$ at $538 \mathrm{~d}$ (Figure 3) led to the following classification similar to that of OTR: $\mathrm{B} 3>\mathrm{B} 2>\mathrm{C} 1, \mathrm{C} 2>$ $\mathrm{C} 4>\mathrm{B} 1$ $\ggg \mathrm{B} 4>\mathrm{C} 3$. This classification was identical to the ratio calculated with $\mathrm{tSO}_{2} \mathrm{C}$ at 370 and 538 days. The only difference was the slightly inverted order between $\mathrm{C} 1$ and $\mathrm{C} 2$ at 370 days for the ratio calculated with $\mathrm{fSO}_{2} \mathrm{C}$. 
Table 4. Ranking comparison OTR vs physicochemical parameters at 538 days. Stoppers B1 to B4; screw caps C1 to C4. OTR in $\mathrm{mg} /$ day/closure; $\mathrm{TO}_{2}$ at equilibrium in $\mathrm{mg} /$ bottle; $\mathrm{fCSO}_{2}$ and $\mathrm{TCO}$ in $\mathrm{mg} / \mathrm{L}$; d: day.

\begin{tabular}{|c|c|c|c|c|}
\cline { 3 - 5 } \multicolumn{2}{c|}{} & \multicolumn{3}{c|}{ OTR and impact of oxygen exposure } \\
\hline Parameter & Range & low & medium & high \\
\hline OTR mg/d & 0.005 to 0.067 & $\mathrm{~B} 2, \mathrm{~B} 3, \mathrm{C} 1, \mathrm{C} 2$ & $<\mathrm{C} 4<\mathrm{B} 1$ & $<<\mathrm{B} 4<<\mathrm{C} 3$ \\
\hline $\mathrm{TO}_{2}$ at equilibrium $\mathrm{mg} / \mathrm{bt}$ & 0.04 to 0.23 & $\mathrm{~B} 2, \mathrm{C} 1<\mathrm{B} 3, \mathrm{C} 2$ & $<\mathrm{B} 1<\mathrm{C} 4$ & $<<\mathrm{B} 4<<\mathrm{C} 3$ \\
\hline$\%$ losses free $\mathrm{SO}_{2} 538 \mathrm{~d}$ & 53 to 70 & $\mathrm{C} 2, \mathrm{C} 1, \mathrm{~B} 2$ & $<\mathrm{B} 3, \mathrm{C} 4<\mathrm{B} 1$ & $<\mathrm{B} 4, \mathrm{C} 3$ \\
\hline$\Delta \mathrm{E}^{*} 538 \mathrm{~d}$ & 6.6 to 8.2 & $\mathrm{C} 4<\mathrm{B} 1<\mathrm{C} 2, \mathrm{~B} 3$ & $<\mathrm{C} 1, \mathrm{~B} 2$ & $<\mathrm{C} 3<\mathrm{B} 4$ \\
\hline $\mathrm{fCSO}_{2} / \mathrm{TCO} 538 \mathrm{~d}$ & 3.9 to 0.5 & $\mathrm{~B} 3, \mathrm{C} 1, \mathrm{C} 2, \mathrm{~B} 2$ & $>\mathrm{C} 4>\mathrm{B} 1$ & $>>\mathrm{B} 4, \mathrm{C} 3$ \\
\hline
\end{tabular}

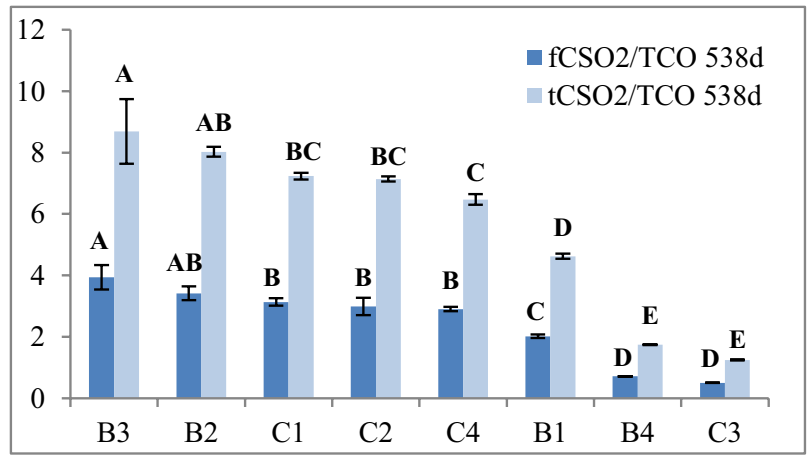

Figure 3. Ratios of free/total Consumed $\mathrm{SO}_{2} / \mathrm{TCO}$ at 538 days. Stoppers $\mathrm{B} 1$ to $\mathrm{B} 4$; screw caps $\mathrm{C} 1$ to $\mathrm{C} 4$. $\mathrm{f}(\mathrm{t}) \mathrm{CSO}_{2} / \mathrm{TCO}$ : free (total) Consumed $\mathrm{SO}_{2} /$ Total Consumed Oxygen. $\mathrm{fCSO}_{2}$, $\mathrm{tCSO}_{2}$ and TCO expressed in $\mathrm{mg} / \mathrm{L}$. Ratios ranked in descending order of $\mathrm{fCSO}_{2} / \mathrm{TCO} 538$ d. Different labels (A, B, C, D, E) indicate means that significantly differ at $p<0.0001$. Averages and standard deviations are based on 3 bottles per procedure.

Logically between these two dates, a decline was observed for all values, highlighting a more intense oxidation over time. As illustrated in Fig. 3, the ratio $\mathrm{tCSO}_{2} / \mathrm{TCO}$ was greater than 4 for the 6 least permeable stoppers. This result has already been observed in previous studies on red wine rich in tannins after 12 and 15 months of storage evidencing oxygen-independent $\mathrm{SO}_{2}$ consumption reactions $[6,36]$.

$\mathrm{TO}_{2}$ at $\mathrm{T} 0$ was between 1.22 and $1.75 \mathrm{mg} / \mathrm{bt}$ according the procedures and average $\mathrm{TO}_{2}$ of corked bottles was $1.30 \mathrm{mg} / \mathrm{bt}$ while it was $1.69 \mathrm{mg} / \mathrm{bt}$ for capped bottles (Table 3). Therefore the caps procedures started with an average handicap of $0.39 \mathrm{mg} / \mathrm{bt}$ compared to the stopper procedures linked to the bottling conditions but independent of the kind of closure. This bias arbitrarily increased the TCO of capped bottles and impacted their sulfites contents without leading the possibility to really quantify it afterwards.

In addition, the OTR of B2 included an estimated (but unmeasured) release of $1.5 \mathrm{mg} /$ stopper. If we considered a release of $2 \mathrm{mg} /$ stopper, mass ratios with $\mathrm{fSO}_{2}$ and $\mathrm{tSO}_{2}$ $538 \mathrm{~d}$ decreased respectively to 3.07 and 7.22 , bringing $\mathrm{B} 2$ behind $\mathrm{C} 2$ and even behind $\mathrm{C} 4$ if we considered the handicap on $\mathrm{TO}_{2}$ at $\mathrm{T0}$ (but excluding the unquantifiable impact on sulfites).

To the more or less accurate assessment of the release of stoppers (in this study, particularly for B2), we must add the high uncertainty on the measurement of free and total $\mathrm{SO}_{2}$ regardless of the analytical method [32].

Finally, all these sources of variation and uncertainty influenced the ratio values and stoppers ranking.

\subsection{Impact of the OTR on physicochemical parameters}

$\mathrm{TO}_{2}$ at equilibrium, $\mathrm{fSO}_{2}$ losses and $\Delta \mathrm{Eab}^{*}$ are physicochemical parameters which are not statistically related to the OTR, but their evolution is influenced by the diffusion of oxygen through the stopper. Table 4 collects these parameters by comparison to OTR and $\mathrm{fCSO}_{2} / \mathrm{TCO}$ ratio at $538 \mathrm{~d}$.

Table 4 showed that the impact of oxygen exposure on the red wine followed the rise of closure OTR. But more than a ranking, it rather evidenced an opposition between B2, B3, C1, C2 and B4, C3; C4 and B1 having an intermediate position.

A matter of fact, $2 \mathrm{mg} / \mathrm{L}$ of $\mathrm{TO}_{2}$ at bottling corresponds to one year of oxygen ingresses by B3, B2, C1 or $\mathrm{C} 2$ closures and $5 \mathrm{mg} / \mathrm{L}$ corresponds to one year of oxygen ingresses by B1 stopper. In addition, previous studies $[37,38]$ on wines stored at ambient temperature show that oxidised characters begin to appear around $12 \mathrm{mg} / \mathrm{L}(9 \mathrm{mg} / 75 \mathrm{cL})$ of oxygen ingresses in the bottle. Thus, given the concerned quantities of oxygen, it is essential to control and manage oxygen at packaging by reducing the targeted amount of total $\mathrm{O}_{2}$ trapped in bottle $\left(\mathrm{TO}_{2}\right.$ at $\mathrm{T} 0$ ) but also its heterogeneity (standard deviation of each lot), so that stopper fully plays its role of oxygen diffuser, especially for wines aimed to be drunk within 18 months.

\subsection{Sensory analyses}

For each analysis time point, jury performances were checked. The panel repeatability and consensus were good.

At 10 months, wines are significantly discriminated by the attribute colour intensity with pvalue $<0.0001$ (Fig. 4). No olfactory and taste differences were observed between the eight procedures. C2 was significantly different from all other procedures by a lighter colour. Then between the seven other wines, the $\mathrm{C} 3$ procedure had a darker colour than B2.

At 17 months, two olfactory descriptors (animal, pvalue $=0.030$ and pepper , pvalue $=0.032$ ) and the visual descriptor (colour intensity, pvalue <0.0001) allowed to discriminate wines (Fig. 4). No taste difference was observed. At olfactory level, we could observe that $\mathrm{C} 2$ and B2 procedures had significantly more intense animal odour than B4. The B2 procedure also had more peppery odour than B1. As at 10 months, C3 procedure had a significantly darker colour particularly than $\mathrm{C} 2, \mathrm{~B} 2$ and $\mathrm{C} 1$.

The evolution of wines in 17 months differed according to the closures. The sensory evolution of wine closed by the four screw cap procedures was important, wines became less bitter and the smell of pepper decreased. 




Figure 4. Means for the significant attributes at 10 and 17 months of storage. Colour Int.: Colour Intensity; m: month. Different labels (A, B, C) indicate means that significantly differ at $* \mathrm{p}<0.0001 ; * * \mathrm{p}<0.030 ; * * \mathrm{p}<+0.032$.

However, the four stoppers procedures had different developments. For B1 and B4 procedures, animal odour decreased. On the contrary, the animal odour of B3 became more intense. About the B2 procedure, the colour of wine became lighter and the intensities of cooked red fruit and pastry decreased.

A graduation of OTR was observable on the basis of animal and colour intensity. Wines with low OTR closures had a more intense animal odour and lighter colour; those with high OTR were darker colour. This observation was made in a previous study on a Grenache wine [5] where it was shown that visual and olfactory differences were observed according to the OTR levels (max. OTR difference: $4.05 \mathrm{mg} /$ year $/ 37.5 \mathrm{cL}$ of wine) but with little impact on taste attributes.

The results obtained by Kwiatokowski et al. [26] with a synthetic cork and a small headspace corroborated our conclusions: a Cabernet Sauvignon wine evolved towards significantly reduced notes, even if these descriptors were not the dominant characteristics of the wines. However, for Ugliano et al. [39], an intake of $1 \mathrm{mg} / \mathrm{O}_{2} /$ year was enough to modify the olfactory characteristics from reduced to fruity; but this conclusion was very dependent on the type of red wine.

\section{Conclusion}

As regards the physicochemical analyses until 18 months, the important points were:

- the average $\mathrm{CO}_{2}$ losses were negligible,

- the free $\mathrm{SO}_{2}$ was always above $10 \mathrm{mg} / \mathrm{L}$, except for $\mathrm{B} 4$ and $\mathrm{C} 3$ closures,

- HSO of B4 and C3 closures stabilised at higher content, while there was not significant difference of DO between all the closures,
- the evolution of the colour was more and more clear with the time $\left(\Delta \mathrm{Eab}^{*} \geq 4.8\right.$ as from $\left.370 \mathrm{~d}\right)$, but it was more due to the aging of wine than to the impact of closure,

- the beneficial effect of storage at $7{ }^{\circ} \mathrm{C}$ for $\mathrm{C} 4$ screw cap was clear on $\mathrm{SO}_{2}$ conservation and protection of the initial colour.

Finally, the ranking of closures from the overall experiment was similar to this of OTR manufacturers, namely from less to more permeable:

$$
\mathrm{C} 1, \mathrm{C2}, \mathrm{B} 2, \mathrm{B3}>\mathrm{C4}>\mathrm{B} 1 \ggg \mathrm{B} 4>\mathrm{C} 3
$$

$\mathrm{C} 1, \mathrm{C} 2, \mathrm{~B} 2$ and $\mathrm{B} 3$ closures were difficult to differentiate, as the oxygen ingress of the first year is around 1.8-1.9 mg for these four closures. The difficulty of finding a link between physicochemical and sensory results mostly came from the fact that between 10 and 18 months, differences of oxygen intakes were low between the stoppers (except for B4 and C3) and wines remained covered by free $\mathrm{SO}_{2}$. But even with the most permeable closures ( $\mathrm{C} 3$ and $\mathrm{B} 4)$, the wines were not systematically characterized by oxidation or aging descriptors.

The study was also conducted on a Colombard and a Rosé de Provence wines under the same conditions of bottling and storage. The physicochemical analyses also highlighted the outlined OTR gradient, but it was mainly on Merlot/Tannat that sensorial analyses were affected by OTR gradient at 17-18 months (data not shown).

The authors thank the CARENE section of UNSCV for its financial support. The authors thank also for their contribution: M. Angènieux, F. Boussuge, F. Dell'Ova, E. Garcia, Y. Sire, 
M. Toussaint, M. Veyret from INRA UEPR and E. Picou from INRA UMR SPO.

\section{References}

[1] A.L. Waterhouse, V.F. Laurie, Am. J. Enol. Vitic. 57, 306-313 (2006)

[2] J.C. Danilewicz, J.T. Seccombe, J. Whelan, Am. J. Enol. Vitic. 59(1), 128-136 (2008)

[3] J.C. Danilewicz, P.J. Wallbridge, Am. J. Enol. Vitic. 61(1), 166-175 (2010)

[4] P. Godden, L. Francis, J. Field, M. Gishen, A. Coulter, P. Valente, P. Høj, E. Robinson, Aust. J. Grape Wine Res. 7(2), 64-105 (2001) doi: 10.1111/j.1755-0238.2001.tb00196.x

[5] S. Caillé, A. Samson, J. Wirth, J.B. Diéval, S. Vidal, V. Cheynier, Anal. Chim. Acta 660(1-2), 35-42 (2009) doi: 10.1016/j.aca.2009.11.049

[6] M. Ugliano, J.B. Diéval, T.E. Siebert, M. Kwiatkowski, O., Aagaard, S. Vidal, E.J. Waters, J. Agric. Food Chem. 60(35), 8561-8570 (2012) doi: $10.1021 /$ jf3014348

[7] J.C.Vidal, M. Moutounet, OENO One 40(1), 35-45 (2006) doi: 10.20870/oeno-one.2006.40.1.884

[8] V. O'Brien, C. Colby, with M. Nygaard, Wine Industry Journal 24(1), 24-29 (2009)

[9] N.Kontoudakis, P. Biosca, R. Canals, F. Fort, J.M. Canals, F. Zamora, Aust. J. Grape Wine Res. 14(1), 116-122 (2008) doi: 10.1111/j.17550238.2008.00013.x

[10] M. Squarzoni, S. Limbo, P. Luciano, Ind. Bevande XXXII, 113-116 (2004)

[11] A. Mas, J. Puig, N. Lladoa, F. Zamora, J. Food Sci. 67(3), 1374-1378 (2002) doi: 10.1111/j.13652621.2002.tb10292.x

[12] C. Puech, S. Vidal, J.F. Pegaz, C. Riou, P. Vuchot, Rev. des Enologues 121, 13-16 (2006)

[13] G.K. Skouroumounis, M.J. Kwiatkowski, I.L. Francis, H. Oakey, D.L. Capone, B. Duncan, M.A. Sefton, E.J. Waters, J. Aust. J. Grape Wine Res., 11(2), 369-377 (2005) doi: 10.1111/j.17550238.2005.tb00036.x

[14] ASTM-Standard-F1927, ASTM Internationals, West Conshohocken, PA

[15] J. Sanchez, J.M. Aracil, Bulletin de l'O.I.V. 71, 805-806 (1998)

[16] J.B. Diéval, S. Vidal, O. Aagaard, Packag. Technol. Sci. 24(7), 375-385 (2011) doi: 10.1002/pts.945

[17] J.C. Vidal, B. Guillemat, C. Chayvialle, Bulletin de l'OIV 84, 962-964 (2011)

[18] P. Lopés, C. Saucier, C., Y. Glories, J. Agric. Food Chem. 53(18), 6967-6973 (2005) doi: 10.1021/jf0404849

[19] M. Poças, B. Ferreira, J. Pereira, T. Hogg, Packag. Technol. Sci. 23, 27-33 (2009) doi: 10.1002/pts.876

[20] P. Lopés, C. Saucier, P.L. Teissedre, Y. Glories, J. Agric. Food Chem. 54(18), 6741-6746 (2006) doi: 10.1021/jf0614239
[21] T. Karbowiak, R.D. Gougeon, J.B. Alinc, L. Brachais, F. Debeaufort, A. Voilley, D. Chassagne, Crit. Rev. Food Sci. 50(1), 20-52 (2009) doi: 10.1080/10408390802248585

[22] C. Macku, K. Reed, K. Practical Winery \& Vineyard Journal, winter 2011 (2011)

[23] M. Brajkovich, N. Tibbits, G. Peron, C.M. Lund, S.I. Dykes, P.A. Kilmartin, L. Nicolau, J. Agric. Food Chem. 53(26), 10006-10011 (2005) doi: 10.1021/jf0512813

[24] P. Chatonnet, D. Labadie, Rev. des Enologues 106, 13-20 (2003)

[25] P. Lopés, M.A. Silva, A. Pons, T. Tominaga, V. Lavigne, C. Saucier, P. Darrier, P., P.L. Teisseidre, D. Dubourdieu, J. Agric. Food Chem. 57(21), 1026110270 (2009) doi: 10.1021/jf9023257

[26] M.J. Kwiatkowski, G.K. Skouroumounis, K.A. Lattey, E.J. Waters, Aust. J. Grape Wine Res. 13(2), 81-94 (2007) doi: 10.1111/j.1755-0238.2007. tb00238.x

[27] J.C. Vidal, E. Devic, F. Dell'Ova, $35^{\text {th }}$ World Congress of Vine and Wine, Izmir, 20 June (2012)

[28] J.C. Vidal, Rev. Fr. CEnol. 272, 2-5 (2015)

[29] J.C. Vidal, M. Moutounet, Internet journal of viticulture and enology 4/3, 1-15 (2011) www. infowine.com

[30] M. Toussaint, J.C. Vidal, J.M. Salmon, J. Agric. Food Chem. 62(13), 2946-2955 (2014) doi: $10.1021 / \mathrm{jf} 405392 \mathrm{u}$

[31] C. Dombre, J. Wirth, M. Toussaint, C. Lixon, A. Verbaere, N. Sommerer, J.C. Boulet, S. Caillé, V. Cheynier, P. Rigou, A. Samson, J.M. Salmon, J.C. Vidal, S. Marais, Y. Gerand, P. Roux, M.H. Lemaîstre, A. Bobe, P. Languet, P. Chalier, Rev. des Enologues 158, 47-50 (2016)

[32] EURL Enologues de France, Bilan des résultats des comparaisons Interlaboratoires (CIL), janv. 2006 à déc. 2015. Union des Enologues de France (2016)

[33] J.C. Danilewicz, Am. J. Enol. Vitic. 67(1), 13-17 (2016) doi: 10.5344/ajev.2015.15069

[34] G. Han, M. Ugliano, B. Currie, S. Vidal, J.B. Diéval, A.L. Waterhouse, J. Sci. Food Agric. 95(1), 36-43 (2014) doi: 10.1002/jsfa.6694

[35] A.L. Waterhouse, S. Frost, M. Ugliano, A.R. Cantu, A.R., B.L. Currie, M. Anderson, A.W. Chasey, S. Vidal, J.B. Diéval, H. Heymann, Am. J. Enol. Vitic. 67(3), 449-459 (2016) doi: 10.5344/ajev.2016.16006

[36] A. Gambuti, T. Siani, L. Picariello, A. Rinaldi, M.T. Lisanti, M. Ugliano, J.B. Diéval, L. Moio, Eur. Food Res. Technol. (2016) doi: 10.1007/s00217016-2780-3

[37] J.C. Vidal, M. Toussaint, J.M. Salmon, $37^{\text {th }}$ World Congress of Vine and Wine, Mendoza, 12023 (2014)

[38] M. Ugliano, J. Agric. Food Chem. 61(26), 6125-6136 (2013) doi: 10.1021/jf400810v

[39] M. Ugliano, J.B. Dieval, S. Begrand, S. Vidal, Rev. des Enologues 156, 45-48 (2015) 